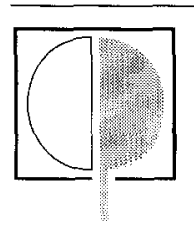

\title{
Bionomics, host plant resistance, and management of the legume pod borer, Maruca vitrata - a review
}

\author{
H. C. Sharma \\ International Crops Research Institute for the Semi-Arid Tropics (ICRISAT) Asia Center, \\ Patancheru 502 324, Andhra Pradesh, India
}

\begin{abstract}
Legume pod borer, Maruca (testulalis) vitrata (Geyer) is one of the major constraints in increasing the production and productivity of grain legumes in the tropics. Screening for resistance has been carried out using natural infestation, and multi- and no-choice tests under greenhouse/laboratory conditions. Information is available on genotypic resistance to $M$. vitrata in cowpea, while such information on pigeonpea and other legumes is limited. Stem and pod wall thickness, trichomes and podding habit are associated with resistance to Maruca. Several natural enemies have been recorded on $M$. vitrata. Cultural practices such as intercropping, weeding, time of planting, and planting density reduce its damage in cowpea. Several insecticides have been found to be effective for controlling this insect. There is a need to generate information on insect-plant-environment interactions, screening techniques, mechanisms and diversity of resistance, genetic transformation of host plants involving $\mathrm{Bt}$ genes, and use of natural enemies for integrated pest management in diverse agro-ecosystems. (C) 1998 Elsevier Science Ltd. All rights reserved
\end{abstract}

Keywords: legume pod borer; Maruca (testulalis) vitrata; plant resistance; resistance mechanisms; natural enemies; cultural and chemical control

\section{Introduction}

The legume pod borer, Maruca (testulalis) vitrata (Geyer) is a serious pest of grain legumes in the tropics and sub-tropics because of its extensive host range, destructiveness, and distribution (Taylor, 1967; Raheja, 1974). It was reported as a pest of beans in Indonesia by Dietz (1914). Its distribution stretches from the Cape Verde Islands in West Africa to Fiji and Samoa in the far East, including the West Indies and Americas (Table 1). Taylor (1978) and Singh and Jackai (1988) have given information on the biology and control of this pest. As this insect is a major constraint in increasing the production and productivity of grain legumes, the major gaps in our knowledge and possible areas of research are identified in this review.

\section{Nature of damage and extent of losses}

\section{Nature of damage}

M. vitrata larvae feed on flowers, buds, and pods by webbing them. This typical feeding habit protects the larvae from natural enemies and other adverse factors, including insecticides. Moths prefer to oviposit at the flower bud stage. Larvae move from one flower to another, and each may consume 4-6 flowers before larval development is completed. Third- to fifth-instar larvae are capable of boring into the pods, and occasionally into peduncle and stems (Taylor, 1967). Moths and larvae are nocturnal (Usua and Singh, 1979). Infestation starts in the terminal shoots (21 days after planting), but later spreads to the reproductive parts (Jackai, 1981). Infestation is highest in flowers $>$ flower buds $>$ terminal shoots $>$ pods. Karel (1985) also observed more larvae $(52.3 \%)$ on flowers than on pods $(37.8 \%)$, and leaves (9.9\%). In pigeonpea, third-instar larvae prefer pods compared to flowers and leaves, and flowers over leaves (Sharma, 1998). First-instar larvae prefer flowers over pods and leaves.

\section{Incidence/extent of losses}

Losses in grain yield have been estimated to range from 20 to $60 \%$ (Singh and Allen, 1980). In Bangladesh, pod borer damage in cowpea was $54.4 \%$ during harvest, but yield loss was estimated to be $<20 \%$ (Ohno and Alam, 1989). Odulaja and Oghiakhe (1993) described a nonlinear model to assess yield loss. Dreyer et al. (1994) observed low seed damage despite heavy flower infestation. Seasonal variation in yield losses was shown in Nigeria, where cowpea yield loss was $72 \%$ in 1985 , and $48 \%$ in 1986. A threshold of $40 \%$ larval infestation in flowers has been established (Ogunwolu, 1990). 
In pigeonpea, incidence and loss in grain yield also varies between seasons and locations (Patel and Singh, 1977; Vishakantaiah and Jagadeesh Babu, 1980; Patnaik et al., 1986; Dharmasena et al., 1992). Plants of ICPL 88007 infested with 8 and 16 larvae resulted in 59.5 and $71.2 \%$ pod damage, and 51.8 and $66.7 \%$ loss in grain yield, respectively. Less damage has been reported in Bangladesh, where pod borers caused $0.9-6.9 \%$ damage to four varieties of country bean (Sarder and Kundu, 1987).

\section{Host range and host plant suitability}

It has been observed to feed on 39 host plants (Table 2) (Akinfenwa, 1975; Atachi and Djihou, 1994). The most frequent host plants are Cajanus cajan, Vigna unguiculata, Phaseolus lunatus, and Pueraria phaseoloids. Growth indices for larvae were 4.14 on pigeonpea, 4.63 on cowpea, and 5.17 on hyacinth bean (Ramasubramanian and Sundara Babu, 1988; Ramasubramanian and Sundara Babu, 1989a). When the number of eggs laid, percentage egg hatch, growth index, and adult emergence were considered, hyacinth bean was identified as the most suitable host for culturing $M$. vitrata.

\section{Bionomics and population dynamics}

Eggs are normally deposited on floral buds and flowers, although oviposition on leaves, leaf axils, terminal shoots, and pods has also been recorded (Bruner, 1931; Wolcott, 1933; Krishnamurthy, 1936; Taylor, 1963, 1967, 1978). A female may lay up to 400 eggs (Okeyo-Owuor and Ochieng, 1981; Jackai et al., 1990). Eggs are light yellow, translucent, and have faint reticulate sculpturing on the delicate chorion, and measure $0.65 \times 0.45 \mathrm{~mm}$ (Taylor, 1967). Eggs are usually deposited in batches of 2 to 16 (Okeyo-Owuor and Ochieng, 1981). Most adults emerge between 20:00 $\mathrm{h}$ and 23:00 h, and 4-5 nights pairing results in highest mating percentage and oviposition. Some males mate more than once, though the majority of females mate only once (Jackai et al., 1990). A one-to-one ratio (10 males:10 females) is optimum for mating and oviposition. Mating takes place between 21:00 $\mathrm{h}$ and 05:00 $\mathrm{h}$ (with a peak between 02:00 and 03:00), when temperatures range between 20 and $25^{\circ} \mathrm{C}$ and $\mathrm{RH}$ over $80 \%$. Females live for $4-8$

Table 1. Distribution of Maruca vitrata.

\begin{tabular}{|c|c|c|c|}
\hline Region & Country & Main host & Reference \\
\hline \multirow[t]{21}{*}{ Asia } & Bangladesh & Country bcan & Das and Islam (1985) \\
\hline & China & Cowpea & Ke et al. (1985) \\
\hline & Indonesia & Yard long bean & Dietz (1914) \\
\hline & India & & \\
\hline & Bihar & Legumes & Saxena $(1978)$ \\
\hline & Andhra Pradesh & Pigeonpea & Rao et al. (1986) \\
\hline & Delhi & Legumes & Saxena (1978) \\
\hline & Gujarat & Greengram & Venkaria and Vyas (1985) \\
\hline & Haryana & Pigeonpea & Srivastava et al. (1992) \\
\hline & Karnataka & Pulses & Krishnamurthy (1936) \\
\hline & Orissa & Pigeonpea & Prasad et al. $(1989 a, b)$ \\
\hline & Uttar Pradesh & Pigeonpea & Patel and Singh (1977) \\
\hline & Madhya Pradesh & Legumes & Saxena $(1978)$ \\
\hline & Tamil Nadu & Grain legumes & Sundara Babu and Rajasekaran (1984) \\
\hline & Japan & Adzuki bean & Katayama and Suzuki (1984) \\
\hline & Malaysia & Long beans & Ibrahim (1980) \\
\hline & Pakistan & Pulses & Ahmed et al. (1987) \\
\hline & Philippines & Grain legumes & Rejesus (1978) \\
\hline & Sri Lanka & Pigeonpea & Subasinghe and Fellows (1978) \\
\hline & Taiwan & Grain legumes & Rose et al. (1978) \\
\hline & Thailand & Pigeonpea & Buranapanichpan and Napompeth (1982) \\
\hline \multirow[t]{12}{*}{ Africa } & Benin & Cowpea & Atachi and Djihou (1994) \\
\hline & Burkina Faso & Groundnut & Traore (1993) \\
\hline & Ghana & Cowpea & Agyen-Sampong (1978) \\
\hline & Kenya & Cowpea & Okeyo-Owuor and Oloo (1991) \\
\hline & Niger & Groundnut & Maiga and Issa (1988) \\
\hline & Nigeria & Cowpea & Singh and Jackai (1988) \\
\hline & Senegal & Cowpea & Ndoye (1978) \\
\hline & Sierra Leone & Grain legumes & Taylor $(1978)$ \\
\hline & South Africa & Cowpea & Phelps and Uostihuizen (1958) \\
\hline & Uganda & Cowpea & Nyiira (1971) \\
\hline & Sudan & Faba bean & Siddig (1982) \\
\hline & Zambia & Beans & Kannaiyan et al. (1987) \\
\hline \multirow[t]{2}{*}{ Australia } & Australia & Adzuki bean & Turner (1978) \\
\hline & Papua and New Guinea & Cowpea & Lamb (1978) \\
\hline North America & USA & Grain legumes & Karel (1984) \\
\hline South & Brazil & Grain legumes & Ruppel and Idrobo (1962) \\
\hline \multirow[t]{3}{*}{ America } & Colombia & Grain legumes & Posada et al. (1970) Schoonhouen (1978) \\
\hline & Cuba & Lima bean and other legumes & Leonard and Mills (1931) \\
\hline & Puerto Rico & Lima bean and other legumes & Leonard and Mills (1931) \\
\hline
\end{tabular}


days. Eggs hatch in 3-6.5 days (Table 3). There are five larval instars (Odebiyi, 1981). Larval development is completed in 8-16.3 days, and prepupal period lasts for 1-2 days. Pupation occurs in the soil in a pupal cell, and lasts for 6.4-11 days. Life cycle is completed in 18-35 days. There is no diapause in this insect, and the populations during the off season are maintained on wild hosts such as Vigna triloba, Crotalaria spp. , Phaseolus spp., and pigeonpea (Taylor, 1967). Development to adult stage is completed only at $22^{\circ} \mathrm{C}$ and $28^{\circ} \mathrm{C}$, and temperatures above $34^{\circ} \mathrm{C}$ were lethal to the larvae (Jackai and Inang, 1992). The lower threshold temperature for pupae was $15.6-17.8^{\circ} \mathrm{C}$, and upper threshold $28-34^{\circ} \mathrm{C}$.

Table 2. Host range of the legume pod borer, Maruca vitrata

\begin{tabular}{|c|c|c|}
\hline Comnion name & Scientific name & Reference \\
\hline \multicolumn{3}{|l|}{ Papilionaceae } \\
\hline Cowpea & Vigna unguiculata & Phelps and Oostihuizen (1958); Taylor (1967) \\
\hline Green gram & Vigna aureus & Visvanathan et al. (1983) \\
\hline Black gram & Vigna mungo & Taylor (1978); Das and Islam (1985) \\
\hline Mung bean & $\begin{array}{l}\text { Vigna radiata } \\
\text { Vigna triloba }\end{array}$ & $\begin{array}{l}\text { Venkaria and Vyas (1985): Das and Islam (1985) } \\
\text { Taylor (1967) }\end{array}$ \\
\hline Pigeonpea & $\begin{array}{l}\text { Cajanus cajan } \\
\text { Cajanus indicus }\end{array}$ & $\begin{array}{l}\text { Taylor (1967); Patel and Singh (1977) } \\
\text { Taylor (1978) }\end{array}$ \\
\hline Hyacinth bean & Dolichos lablab & Ramasubramanian and Sundara Babu (1988) \\
\hline Country bean & Lablab purpureus & Das and Islam (1985) \\
\hline Kidney bean & Phaseolus vulgaris & Rejesus (1978): Taylor (1978) \\
\hline Lima bean & Phaseolus lunatus & Leonard and Mills (1931); Atachi and Djihou (1994) \\
\hline Adzuki bean & Phaseolus angularis & Katayama and Suzuki (1984) \\
\hline Broad bean & Vicia faba & Siddig (1982) \\
\hline Yard long bean & Vigna sinensis & Satsijati et al. (1986) \\
\hline Fusi-sasagc & Vigna vexillata & Oghiakhe et al. (1993d) \\
\hline Long bean & Vigna sesquipedalis & Ibrahim $(1980)$ \\
\hline Winged bean & Psophocarpus tetragonolobus & Taylor (1978) \\
\hline Soya bedil & Glycine max & Das and Islam (1985) \\
\hline Groundnut & Arachis hypogea & Taylor (1978); Traore (1993) \\
\hline \multirow[t]{2}{*}{ African yam bean } & Sphenostylis stenocarpa & Taylor (1978) \\
\hline & Gliricidia sepium & Taylor (1978) \\
\hline Grass pea & Lathyrus sativus & Das and Islam (1985) \\
\hline \multirow[t]{3}{*}{ Field pea } & Pisum sativum & Das and Islam (1985) \\
\hline & Pueraria phaseoloids & Atachi and Djihou (1994) \\
\hline & Stizolobium sp. & Taylor $(1978)$ \\
\hline \multirow[t]{10}{*}{ Valvet bean } & Mucuna sp. & Taylor (1978) \\
\hline & Tephrosia candida & Taylor (1978) \\
\hline & Tephrosia purpurea & Taylor (1978) \\
\hline & Crotalaria juncea & Jackai and Singh (1983) \\
\hline & Crotalaria mucronata & Jackai and Singh (1983) \\
\hline & Crotalaria incana & Jackai and Singh (1983) \\
\hline & Crotalaria retusa & Atachi and Djihou (1994) \\
\hline & Crotalaria amazonas & Jackai and Singh (1983) \\
\hline & Crotalaria saltiana & Jackai and Singh (1983) \\
\hline & Crotalaria misereniensis & Jackai and Singh (1983) \\
\hline \multicolumn{3}{|l|}{ Cesalpinaceae } \\
\hline \multirow{2}{*}{ Pedaliaceac } & Panciana sp. & laylor (19/8) \\
\hline & Sesamum sp. & Taylor (1978) \\
\hline \multirow[t]{2}{*}{ Malvaceae } & & \\
\hline & Hibiscus sp. & Taylor (1978) \\
\hline Mimosaceae & Escelerona dolabrifomis & Taylor (1978) \\
\hline
\end{tabular}

Table 3. Development of legume pod borer, Maruca vitrata on different host plants

\begin{tabular}{lcccccc}
\hline & & \multicolumn{2}{c}{ Development period (days) } \\
\cline { 2 - 6 } Host plant & Egg & Larval & Pre-pupal & Pupal & Total & Reference \\
\hline Cowpea & 5 & $8-14$ & 2 & 7 & $18-35$ & Taylor (1967); Booker (1965); Akinfenwa (1975) \\
& 3 & $8-14$ & 1 & $5-14$ & $25-27$ & Okeyo-Owuor and Ochieng (1981) \\
Pigeonpea & 3.1 & 13.9 & 1.8 & 6.9 & 25.7 & Ramasubramanian and Sundara Babu (1988, 1989a) \\
& 3.1 & 12.7 & 2.1 & 8.7 & 26.5 & Vishakantaiah and Jagadeesh Babu (1980) \\
Country bean & 2.9 & 13.3 & 1.5 & 6.4 & 24.1 & Ramasubramanian and Sundara Babu (1988, 1989a) \\
Hyacinth bean & $3-4$ & $11-14$ & $1-2$ & $8-11$ & $21-23$ & Sharma (1998) \\
\hline
\end{tabular}


Larvae of $M$. vitrata are dispersed randomly on flowers of cowpea (Firempong and Mangalit, 1990). Initial infestation on cowpea in Nigeria occurs when adults emerge from alternate hosts (Taylor, 1967). Peak infestation occurs on the early sown crop in June-July. The first generation adults on cowpea emerge in July, and the second between July and September. Adults have been observed in light traps in most months, although the catches are low during the off-season. The insects possibly migrate from South to North associated with movements of the inter-tropical convergence zone, and moving South in November-December. Adults have been caught in light traps between 18:40 and 00:45 $\mathrm{h}$, with a peak between 20:00 and 21:00 h (Akinfenwa, 1975). Okeyo-Owuor et al. (1983) reported that in Kenya, pod borer populations are lower during the short rainy season, but infestation is continuous unless flower and pod production ceases. Atachi and Ahohuendo (1989) obscrved maximum larval density 40 DAP (days after planting) on four cultivars, and 47 DAP on six cultivars (4-17 larvae per 20 flowers) in Benin. Highest infestation of flowers was recorded on the same sampling date on all cultivars $(20-70 \%)$.

At ICRISAT Center, moth catches were greatest between early November to mid-December in the light traps (Srivastava et al., 1992) with a peak during November (in 46 and 47 standard weeks). At Hisar, maximum moth activity has been observed from mid-September to mid-October. Akhauri et al. (1994) observed that the larval density increased from mid-October to the end of November at Dholi, Bihar, India on early pigeonpea. The peak in larval density occurred in the last week of November. In Sri Lanka, Saxena et al. (1992) observed a high larval density in the crop planted in mid-October. Alghali (1993a) observed three peaks of pod borer infestation in cowpea. Significant relationships were observed between pod borer incidence and cumulative rainfall, and number of rainy days between crop emergence to flowering.

\section{Mass rearing}

Ochieng et al. (1981) developed a procedure for mass rearing, which allows production of over 75000 eggs per month. Jackai and Raulston (1982), Jackai and Raulston (1988) and Ochieng and Bungu (1983) attempted rearing of $M$. vitrata on an artificial diet, but the performance of the laboratory reared insects declined after a few generations. Onyango and Ochieng-Odero (1993) developed a diet on which the fecundity of the females increased with advancing generations: adult emergence ranged between 70 and $90 \%$, one litre of diet produced nearly 400 adults, and a female laid $>200$ eggs.

\section{Screening for resistance}

\section{Field screening techniques}

Screening for resistance to pod borers can be carried out during March-April and August-September in Nigeria, when pod borer density is high. Planting infester rows 2 weeks earlier than the test cultivars, and uprooting the infester rows running parallel to the test material after 6 weeks (Jackai, 1982), spraying experimental plots at the flower bud stage to suppress thrips and hemipterans, and keeping the greenhouse or the field plots moist (Singh and Jackai, 1988) helps to improve the efficiency of screening for resistance to the pod borer. An infestation level of two larvae per plant was enough to detect differences in flower and pod damage, and grain yield between infested and uninfested plants (Echendu and Akingbohungbe, 1989). Flower, pod and seed damage (Jackai, 1982; Valdez, 1989), larval population in flowers and ratio of grain yield under protected and unprotected conditions (Wooley and Evans 1979), and pod evaluation index (ratio of pod load to pod damage) (Oghiakhe et al., 1992a) have all been suggested as criteria to select for resistance to pod borer.

\section{Greenhouse/laboratory screening techniques}

Field screening is often difficult due to low or unknown levels of insect infestations. Artificial infestation of the test plants under field/greenhouse conditions can be used to overcome this problem. Expression of cowpea resistance to Maruca is affected by plant growth stages (Dabrowski et al., 1983). Plants with five to seven shoots are most suitable for resistance screening prior to flowering. Using five eggs per plant at this stage, it was possible to differentiate between the resistant and susceptible lines, but 10 eggs per plant is optimum. Echendu and Akingbohungbe (1990), using free- and no-choice techniques, confirmed the results obtained under field conditions. Jackai (1991) used a dual-choice arena test (DCAT) for $72 \mathrm{~h}$, and calculated the relative resistance of a test line compared with either the susceptible or resistant check using a feeding index. In the second assay (intact pod test, IPT) - a no-choice test was conducted in a screenhouse for 2 weeks. Using this test, conclusive information on seed damage could be obtained after $72 \mathrm{~h}$ of feeding exposure. In this test, TVNu 72 showed resistance similar to that determined by the DCAT. The two assays are complementary and provide useful information on antixenosis and antibiosis components of resistance, and can be used in sequence. Infesting pigeonpea plants with 10 first-instar larvae, and covering with a cloth bag placed around a wireframed cage ( $40 \mathrm{~cm}$ in diameter, $45 \mathrm{~cm}$ long) can be used to screen for resistance to the pod borer (Sharma, 1998). 'The plants may be evaluated for insect damage 15 days after infestation. This technique can be used to confirm the resistance observed under field conditions, and determine resistance levels in different cultivars.

\section{Sources of resistance}

\section{Cowpea}

Several genotypes showing moderate to high levels of resistance to Maruca damage have been identified 
(Table 4). TVu 946, showing high levels of resistance across seasons and locations, can be utilized in breeding programs (Jackai, 1981). Oghiakhe and Odulaja (1993a) used principal component analysis to study the variation patterns in 18 cowpea cultivars developed for resistance to $M$. vitrata based on seven developmental parameters of the pest on floral buds, flowers, and sliced pods. Percentage pupation, adult emergence, and growth index were important for the grouping of the cultivars. Growth index had the highest factor score. Using cluster analysis, Oghiakhe and Odulaja (1993b) found that MRx 6-84F has wider adaptability in the presence of Maruca infestation. $\mathrm{TVu} 946$ performed best, and was in a single cluster. Mokwa, MRx 2-84F, MRx 5-84F, MRx 6-84F, MRx 54-84M, MRx 8-84F, MRx 49-84M, and MRx $50-84 \mathrm{~F}$ were grouped together. Expression of resistance to the pod borer is influenced by variety and environment (Suh and Simbi, 1983), and intercropping (Gethi et al., 1993). Resistance of TVu 946 was reduced when intercropped with maize. This has been attributed to increase in pod and peduncle length, and a significant reduction in the number of branches. Intercropping also resulted in significant differences in temperature, R.H., and a reduction in photosynthetic activity. Wooley and Evans (1984) have described a methodology to breed for resistance to pod borer in cowpea.

\section{Pigeonpea}

Low to moderate levels of resistance have been observed in pigeonpea genotypes against pod borer damage (Table 4). Early maturing pigeonpea varieties suffer greater damage than the late maturing varieties (Sahoo and Patnaik, 1993). Indeterminate type lines are in general less damaged than the determinate types (Lateef and Reed, 1981; Saxena et al., 1996).

\section{Mechanisms of resistance}

\section{Antixenosis}

Ramasubramanian and Sundara Babu (1989b) observed that hyacinth bean was preferred for oviposition, followed by cowpea and pigeonpea. Maximum number of eggs were laid 3 days after mating on the preferred host, while on cowpea and pigeonpea, the highest number of eggs were laid on the fourth day after mating. Cowpea cultivar TVu 946 exhibits

Table 4. Sources of resistance to Maruca vitrata in pigeonpea and cowpea

\begin{tabular}{|c|c|c|}
\hline Genotype & Remarks & Reference \\
\hline \multicolumn{3}{|l|}{ Pigeonpea } \\
\hline ICPL 81, Pusa 33, and $\mathrm{H}$ 76-208 & Less susceptible compared to ICPL 1 and ICPL 151 & Patnaik et al. (1986) \\
\hline Pusa 855 & $\begin{array}{l}\text { Low pod damage compared } \\
\text { to I } 14 \text { and ICPL } 106 \\
\text { over two seasons }\end{array}$ & Prasad et al. (1989a) \\
\hline MTH 8, Phule T 17, and MTH 9 & Lower pod damage than BR 65 & Prasad et al. (1989b) \\
\hline MPG 359, MPG 531, MPG 532, and MPG 566 & $\begin{array}{l}\text { Suffered a damage rating of }<3 \text {, } \\
\text { and are determinate types }\end{array}$ & Saxena et al. (1996) \\
\hline $\begin{array}{l}\text { MPG 537, MPG 664, MPG 665, MPG } 359 \text {, } \\
\text { ICPL 88034, ICPL 89038, MPG 662, } \\
\text { ICPL 87115, ICPL 90037, ICPL 89016, } \\
\text { ICPL 85045, and ICPL 86020 }\end{array}$ & $\begin{array}{l}\text { Yielded greater than ICPL } 2 \text { and } \\
\text { suffered } 10-25 \% \text { pod borer damage. } \\
\text { Tolerant to pod borer damage }\end{array}$ & Saxena et al. (1996) \\
\hline ICP 809 and T 21 & $\begin{array}{l}\text { Also tolerant to podfly and } \\
\text { Helicoverpa }\end{array}$ & Saxena et al. (1996) \\
\hline ICPL 85010 and ICPL 90011 & $\begin{array}{l}\text { Less suitable for growth and } \\
\text { development of larvae }\end{array}$ & Sharma (1998) \\
\hline \multicolumn{3}{|l|}{ Cowpea } \\
\hline $\begin{array}{l}\text { TVu 946, TVu } 4557 \text { (VITA 5), } \\
\text { VITA } 4 \text {, and Ife Brown }\end{array}$ & $\begin{array}{l}\text { Showed resistance to peduncle } \\
\text { damage. TVu } 946 \text { and TVu } 4557 \text { also } \\
\text { showed resistance to flower damage }\end{array}$ & Singh (1978) \\
\hline $\begin{array}{l}\text { New Era 169, SES no.5, IR 58-162, } \\
\text { Wake Jaba, and Idad Market }\end{array}$ & $\begin{array}{l}\text { Moderate to high levels of } \\
\text { resistance to post-flowering pests } \\
\text { as measured by seed yield ratio }\end{array}$ & Wooley and Evans (1979) \\
\hline TVu 946 and VIIA & $\begin{array}{l}\text { Less number of larvae in } \\
\text { different plant parts }\end{array}$ & Jackai (1981) \\
\hline $\begin{array}{l}\text { TVu } 946, \text { Kamboinse local, TVu } 1 \text {, } \\
\text { VITA } 5 \text {, TVx } 3890-010 \mathrm{~F} \text {, and } \\
\text { VICA M- } 1 / 5 \mathrm{P}\end{array}$ & TVu 946 was most resistant & Jackai (1982) \\
\hline TVu 946, Ife Brown, and VITA 1 & $\begin{array}{l}\text { Showed resistance in field } \\
\text { and screenhouse experiments }\end{array}$ & Macfoy et al. (1983) \\
\hline $\begin{array}{l}\text { IT } 82 \mathrm{E}-32, \mathrm{IT} 82 \mathrm{E}-77, \mathrm{IT} 82 \mathrm{E}-18 \\
\text { TVx } 1843-1 \mathrm{C}, \mathrm{ER} 7, \text { and } \\
\text { Tvu } 72-59-25\end{array}$ & Less susceptible & Marfo (1985) \\
\hline $\begin{array}{l}\text { CES } 15-27, \text { TVu } 461, \text { TVu 1061-1, } \\
\text { TVu 1248, TVu 1499-1, TVu } 3 \\
\text { (Local Brown), and TVu } 946\end{array}$ & $\begin{array}{l}\text { Less susceptible under field } \\
\text { conditions }\end{array}$ & Valdez (1989) \\
\hline $\begin{array}{l}\text { MRx 6-84F, TVu 946, Mokwa, } \\
\text { MRx 2-84F, MRx 5-84F, } \\
\text { MRx 54-84M, MRx 8-84F, } \\
\text { MRx 49-84M, and MRx 50-84F }\end{array}$ & $\begin{array}{l}\text { Based on cluster analysis, } \\
\text { MRx } 6-84 \mathrm{~F} \text { showed wide adaptability } \\
\text { TVu } 946 \text { was placed in a single cluster }\end{array}$ & Oghiakhe and Odulaja (1993b) \\
\hline
\end{tabular}


nonpreference for oviposition compared to Ife Brown and Vita 1 (Macfoy et al., 1983). However, Valdez (1989) indicated that there is no oviposition antixenosis in cowpea to the pod borer. Nonpreference to larval feeding has been reported by Echendu and Akingbohungbe (1990). Attraction and arrest-stay of first-instar larvae contribute to the resistance of $\mathrm{TVu}$ 946 and VITA 5 to the pod borer (Okech and Saxena, 1990).

\section{Antibiosis}

Survival of the larvae is low on TVu 946, and this is due to nutritional and antibiotic factor(s) (Macfoy et $a l ., 1983)$. Valdez (1989) observed only a slight effect of the host on larval survival. Oghiakhe et al. (1993c) reared larvae successfully on floral buds, flowers, and sliced pods, but not on stems, terminal shoots, and intact pods. Sliced pods were most suitable for growth and development, followed by flowers, and flower buds. Okech and Saxena (1990) indicated that antibiosis was a component of resistance in TVu 946 and VITA 5 stems and pods. Highest larval weight gain was recorded on TVu 3 and least in CES 15-27. Consumption index (CI) was higher on TVu 1248 and TVu 1 compared to CES 15-27, TVu 161-1-2, TVu 461, TVu 946, TVu 1016-1, and TVu 1499-1. On pigeonpea, the third-instar larvae consumed 27.0 to $47.2 \mathrm{mg}$ food on the flowers, and had growth rates of $114.7 \%$ on ICPL 88020 to $207.3 \%$ on ICPL 85010 . Approximate digestibility (AD) was lower on ICPL 85010 than on ICPL 90011. Efficiency of conversion (ECI) of ingested food into body matter was lower on ICPL 90011 compared to ICPL 85010 and ICPL 88007 . The fifth-instar larvae consumed 52.3 to 80.6 $\mathrm{mg}$ of food on pods, and showed growth rates of 30.1 to $41.8 \%$. ECI was lowest on ICPL 90011, followed by that on ICPL 88020 , ICPL 88007 , and ICPL 85010 (Sharma, 1998). Thus, some of the pigeonpea genotypes are less suitable for the growth and dcvelopment of pod borer, which may be due to nutritional or antibiotic factors.

\section{Tolerance}

ICPL 88034 and MPG 679, showing low Maruca damage (10-25\%), have excellent recovery from damage. These lines need to be evaluated to confirm their tolerance to Maruca (Saxena et al., 1996).

\section{Factors associated with resistance}

\section{Plant architecture}

Singh (1978) reported that resistance of TVu 946 and $\mathrm{TVu} 4557$ is due to long peduncles, pods held over the plant canopy and at a wider angle than the normal. Oghiakhe et al. (1991a) observed that defoliated cultivars suffered lower damage than the undefoliated ones. Percentage pod damage and larval infestation in flowers were positively correlated with R.H. and negatively with temperature. Cowpea genotypes with bunched pods suffer greater damage
(Usua and Singh, 1979). Oghiakhe et al. (1992b) observed negative relationships between pod angle and pod damage, and seed damage index in two cowpea cultivars. Pods with wide angles $\left(>89^{\circ}\right)$ were damaged on one side, and rarely on both sides. Erect and profuse flowering contributed to the resistance of TVu 946 to $M$. vitrata (Oghiakhe et al., 1993b). Tayo (1988) reported that the period of flower opening spanned over 13 days in TVu 946, 17 days in ICV 2, and 18 days in Vita 1 . About $85-100 \%$ of the pods retained to maturity were from flowers opening within 8 days of anthesis. The efficiency of pod production from open flowers was highest in TVu 946 (54\%), lowest in Vita $1(11 \%)$, and median in ICV 2 $(31 \%)$. Pod elongation and enlargement were initially rapid in all varieties, but pods in TVu 946 reached physiological maturity 2 days earlier than the other varieties. Open canopy, long peduncles, erect pods with wide angles, profuse flowering, pod size, and rate of pod growth can be used to select for resistance to $M$. vitrata.

In pigeonpea, determinate lines with clustered inflorescence were more susceptible than the indeterminate types (Saxena et al., 1996). Only four determinate lines (MPG 359, 531, 532, and 566) suffered a damage rating of $<3$, while 12 indeterminate lines had a damage rating of $<3$. Fifty-six percent of indeterminate lines had $<50 \%$ damage in contrast to $15 \%$ of the detcrminatc lines, confirming the suggestion made by Lateef and Reed (1981).

\section{Anatomical characteristics}

Stem epidermis influences both larval movement and feeding within the stem tissue (Oghiakhe et al., 1991b). Collenchyma cells in 21-day old TVu 946 and IT 82D-716 stems form a network of closely knit interlocking cells with a few intercellular spaces. Significant differences have been observed in the distance between the epidermis and collenchyma cells of the slightly raised (convex) and concave portions of TVu 946 and IT 82D-716 stems. TVu 946 has a smaller stem diameter than IT 82D-716 stem. Distance between epicarp and mesocarp tissues of 7-day old TVu 946 and IT 82D-716 pod wall did not show any significant differences. Stem tissue structure (epidermis and collenchymma cells) is an important factor in stem resistance to $M$. vitrata, but this does not appear to be the case in pod wall resistance (Oghiakhe et al., 1992c). Feeding and development is adversely affected on two wild cowpea (Vigna vaxillata) accessions (TVNu 72 and TVNu 73) compared to the susceptible variety IT 84E-124 (Jackai and Oghiakhe, 1989). Maruca larvae fed and developed better when the trichomes were removed. Growth index was $13 \times$ less when the trichomes were left intact both on TVNu 72 and TVNu 73. The resistance of these lines was based on trichomes and phyto-chemicals. Oghiakhe et al. (1993a) observed an uncharacteristic network of fibrous structures on the petals of TVNu 72, but not on the susceptible control IT 82D-716. The stems had thick and closely packed collenchyma cells and both have resistance to stem feeding. Trichomes are the principle factor in TVNu 
72 resistance to $M$. vitrata. Trichomes varied in length and density, but not in type on different plant parts (Oghiakhe et al., 1992d). Significant correlations were observed between trichome density and pod borer damage.

\section{Biochemical factors}

Sugar content in the pod walls of TVNu 72 is greater than in IT 82D-716, and phenol content is lower in the pod wall of TVNu 72, but the reverse is true for fresh and dry seeds (Oghiakhe et al., 1993a). Neither sugars nor phenols seem to be involved in the resistance of TVNu 72 to $M$. vitrata (Oghiakhe et al., $1993 \mathrm{c}, 1993 \mathrm{~d})$. Phenol concentration varies significantly between different plant parts, and generally decreases with an increase in plant age. Otieno $e t a l$. (1985) indicated that ethyl-acetate soluble fraction of methanol extracts of stems of TVu 946 showed significantly greater feeding inhibition than the extract from ICG 1.

\section{Natural enemies}

Several parasites and predators have been recorded on M. vitrata by Usua and Singh (1977), Barrion et al. (1987) and Vishakantaiah and Jagadeesh Babu (1980) (Tables 5 and 6). Okeyo-Owuor and Oloo (1991) observed that mortality from the egg to adult stage was $98.2-99.4 \%$ in Kenya. Highest mortality occurred between egg stage and the third-instar larvae. The

Table 5. Parasitoids of the legume pod borer, Maruca vitrata

\begin{tabular}{|c|c|c|}
\hline Parasitoid & Life stage parasitized & Reference \\
\hline \multicolumn{3}{|l|}{ Diptera } \\
\hline Aplomya metallica (Weid.) & Larva & Agyen-Sampong (1978) \\
\hline Exorista xanthaspis (Wiedemann) & Larva & Barrion et al. (1987) \\
\hline Palexorista solemnis (Walker) & Larva & Barrion et al. (1987) \\
\hline Peirbaea orbata (Wiedemann) & Larva & Barrion et al. (1987) \\
\hline Zygobothria atropivora (Rob.-Desv.) & Larva & Barrion et al. (1987) \\
\hline Zygobothria ciliata (Wulp) & Larva & Barrion et al. (1987) \\
\hline Thelairosoma sp. & Larva & Usua and Singh (1977) \\
\hline Pseudoperichaeia laevis (Vill.) & Larva & Agycn-Sampong (1978) \\
\hline Pseudaporichaeta sp. & Larva & Usua and Singh (1977) \\
\hline The cocarcelia incedens (Rond.) & Larva & Agyen-Sampong (1978) \\
\hline \multicolumn{3}{|l|}{ Hymenoptera } \\
\hline \multicolumn{3}{|l|}{ Baraconidae } \\
\hline Apanteles sp. & Larva & Okeyo-Owuor et al. (1991) \\
\hline Bracon greeni Ashm. & Larva & ICRISAT (1981) \\
\hline Bracon sp. & Larva & Okeyo-Owuor et al. (1991) \\
\hline Braunsia sp. & Pupa & Okeyo-Owuor et al. (1991); Agyen-Sampong (1978) \\
\hline Cardiochiles philippinensis Ashm. & Larva & Barrion et al. (1987) \\
\hline Chelonus sp. & Larva & Barrion et al. (1987) \\
\hline Cremnops sp. & Larva-Pupa & Barrion et al. (1987) \\
\hline Snellenius manilue Ashm. & Larva & Barrion et al. (1987) \\
\hline Phanertoma handecasisella Cam. & Larva & ICRISAT (1978); Subasinghe and Fellows (1978) \\
\hline Phanertoma sp. & I arva & Usua and Singh (1977) \\
\hline \multicolumn{3}{|l|}{ Chalcididae } \\
\hline Antrocephalus sp. nr subelongatus Kohl & - & Subasinghe and Fellows (1978) \\
\hline Antrocephalus sp. & Pupa & Okeyo-Owuor et al (1991) \\
\hline Brachymeria sp. A. & Larva-pupa & Barrion et al. (1987) \\
\hline Brachymeria sp. B. & Larva-pupa & Barrion et al. (1987) \\
\hline \multicolumn{3}{|l|}{ Eulophidae } \\
\hline Nesolynx thymus (Gir.) & - & Subasinghe and Fellows (1978) \\
\hline Tetrastichus sesamiae Risbec & Pupa & Okeyo-Owuor et al. (1991) \\
\hline Tetrasichus sp. & Pupa & Barrion et al. (1987); Usua and Singh (1977) \\
\hline \multicolumn{3}{|l|}{ lchneumonidae } \\
\hline Caenopimpla arealis (Cushman) & Larva & Barrion et al. (1987); Usua and Singh (1977) \\
\hline Charops nigrita Gupta and Maheswary & Larva & Barrion et al. (1987); Usua and Singh (1977) \\
\hline Meloboris sinicus (Holmgren) & Larva & Barrion et al. (1987); Usua and Singh (1977) \\
\hline Metopius rufus browni Ashm. & Larva & Barrion et al. (1987); Usua and Singh (1977) \\
\hline \multicolumn{3}{|l|}{ Pteromalidae } \\
\hline Trichomalopsis sp. & Larva-pupa & Barrion et al. (1987) \\
\hline \multicolumn{3}{|l|}{ Scelionidae } \\
\hline Telenomus sp. & - & Subasinghe and Fellows (1978) \\
\hline \multicolumn{3}{|l|}{ Acarina } \\
\hline Dinothrombius sp. & Larva & Agyen-Sampong (1978) \\
\hline Nematodes & Larva-Pupa & Okeyo-Owuor et al. (1991) \\
\hline \multicolumn{3}{|l|}{ Protozoa } \\
\hline Mettesia $\mathrm{sp}$. & I arva-Pupa & Okeyo-Owuor et al. (1991) \\
\hline Nosema marucae sp. $\mathrm{n}$. & Larva-Pupa & Odindo and Jura (1992) \\
\hline Nosema sp. & Larva-Pupa & Okeyo-Owuor et al. (1991) \\
\hline \multicolumn{3}{|l|}{ Bacteria } \\
\hline Bacillus sp. & Larva-Pupa & Okeyo-Owuor et al. (1991) \\
\hline Colostridium sp. & Latva-Pupa & Okeyo-Owuor et al. (1991) \\
\hline
\end{tabular}


causes of mortality were disappearance, followed by disease and parasitism. Seven parasitoids, two predators, one nematode, and several pathogens were recorded (Okeyo-Owuor et al., 1991; Otieno et al., 1983; Otieno, 1989). A pupal endoparasitoid, Antrocephalus sp. was the predominant natural enemy, while Nosema sp. and Bacillus sp. caused the highest natural mortality. Parasitoids and pathogens contributed $41 \%$ and $36 \%$ to the total generation mortality $(K)$ at two sites, respectively, but observed that parasitism contributed $<4 \%$. Mortality due to disappearance, which also included predation, accounted for about $60 \%$ of $K$. Life table data and survival curves revealed high mortality (ca. 98\%), most of which occurred in the early life stages. So, there is a high potential for utilizing biocontrol agents for the management of this pest.

\section{Cultural practices}

\section{Planting time}

Pod borer populations tend to build up over the season (Ekesi et al., 1996). Thus, pod borer infestation increases on the late sown crop (Alghali, 1993a). Grain yield also decreases in late planted crops. Simultaneous plantings of maize and cowpea increase pod borer infestation in cowpea (Ezueh and Taylor, 1984), whereas sowing cowpea 12 weeks after maize reduces the pod borer damage.

\section{Intercropping}

Pod borer damage in a monocrop is greater than the maize-cowpea-sorghum inter-mixed crops (AmoakoAtta and Omolo, 1982; Amoako-Atta et al., 1983; Fisher et al., 1987; Omolo et al., 1993). Pod borer incidence was significantly lower in intercropped and higher plant populations than in pure stands, and in a lower plant population of common bean, Phaseolus vulgaris (Karel, 1984, 1993). Flower and pod damage was significantly lower in an intercrop combination of one third bean-two thirds maize, so intercropping maize with bean was considered useful as a cultural method for controlling pod borers in common bean. However, Alghali (1993b), Ofuya (1991), Natarajan et al. (1991), Patnaik et al. (1989) and Saxena et al. (1992) reported no effect of intercropping on the incidence of $M$. vitrata.

\section{Weeding}

Cowpea weeded two, three or four times had less flowcr infestation by $M$. vitrata than the non-weeded plots (Ofuya, 1989). However, effects of weeding

Table 6. Predators of the bean pod borer Maruca vitrata

\begin{tabular}{|c|c|c|}
\hline Predator & Life stage attacked & Reference \\
\hline \multicolumn{3}{|l|}{ Dermaptera } \\
\hline Diaperastichus erythrocephala $\mathrm{Ol}$ & Larva/pupa & Okeyo-Owuor et al. (1991) \\
\hline \multicolumn{3}{|l|}{ Dictyoptera } \\
\hline \multicolumn{3}{|l|}{ Mantidae } \\
\hline Polyspilota sp. & Moths & Usua and Singh (1977) \\
\hline Spodromantis sp. & Moths & Usua and Singh (1977) \\
\hline \multicolumn{3}{|l|}{ Coleoptera } \\
\hline \multicolumn{3}{|l|}{ Carabidae } \\
\hline Chlaenius sp. A & Larva & Barrion et al. (1987) \\
\hline Chlaenius sp. B & Larva & Barrion et al. (1987) \\
\hline Cicindela lacrymosa $(\mathrm{F})$. & Larva & Barrion et al. (1987) \\
\hline \multicolumn{3}{|l|}{ Coccinellidae } \\
\hline Coccinella repanda (Thunberg) & Larva & Barrion et al. (1987) \\
\hline Menochilus sexmaculatus (F.) & Larva & Barrion et al. (1987) \\
\hline Synharmonia octomaculata (F.) & Larva & Barrion et al. (1987) \\
\hline \multicolumn{3}{|l|}{ Hemiptera } \\
\hline \multicolumn{3}{|l|}{ Anthocoridae } \\
\hline Orius tantillus Motsch. & Egg and larva & Barrion et al. (1987) \\
\hline \multicolumn{3}{|l|}{ Hymenoptera } \\
\hline \multicolumn{3}{|l|}{ Formicidae } \\
\hline Camponotus sericeus Fab. & Larva & Usua and Singh (1977) \\
\hline $\begin{array}{l}\text { Camponotus rufoglaucus (Jerd.) } \\
\text { Vespidae }\end{array}$ & Larva & Okeyo-Owuor et al. (1991) \\
\hline ? Eumenes sp. & Larva & Barrion et al. (1987) \\
\hline Ropalialae flavopicta favobrunnea van der Vecht & Larva & Barrion et al. (1987) \\
\hline \multicolumn{3}{|l|}{ Araneida } \\
\hline \multicolumn{3}{|l|}{ Selenopidae } \\
\hline Selenops sp. & Larva and adult & Usua and Singh (1977) \\
\hline \multicolumn{3}{|l|}{ Araneidae } \\
\hline $\begin{array}{l}\text { Nephila maculata (F.) } \\
\text { Oxyopidae }\end{array}$ & Adult & Barrion et al. (1987) \\
\hline $\begin{array}{l}\text { Oxyopidae } \\
\text { Oxyopes javanus Thorell }\end{array}$ & & \\
\hline \multicolumn{3}{|l|}{$\begin{array}{l}\text { Oxyopes javanus inorell } \\
\text { Salticidae }\end{array}$} \\
\hline Evarcha sp. & Adult & Barrion et al. (1987) \\
\hline Marpissa bengalensis Tikader & Adult & Barrion et al. (1987) \\
\hline Marpissa calcutaensis Tikader & Adult & Barrion et al. (1987) \\
\hline \multicolumn{3}{|l|}{ Sparassidae } \\
\hline Heteropoda venatoria $(\mathrm{L})$. & Adult & Barrion et al. (1987) \\
\hline
\end{tabular}


frequency on pod damage by $M$. vitrata are not consistent and Akinyemiju and Olaifa (1987) and Ezueh and Amusan (1988) concluded that weed control did not affect borer damage.

\section{Chemical control}

Endosulfan (applied at 35 DAP twice at weekly intervals) (Dina and Medaiyedu, 1976; Jackai, 1983); one spray of cypermethrin, biphenthrin, cyhalothrin, and in combination with dimethoate (Amatobi, 1994); a mixture of cypermethrin+dimethoate (using Electrodyn sprayer (Jackai et al., 1987; Ezueh, 1990); or two applications of cypermethrin+dimethoate at 10 day intervals (beginning at bud formation) (Amatobi, 1995) give effective control of the pod borer on cowpea.

On pigeonpea, deltamethrin, cypermethrin, and fluvalinate (Bhalani and Prasana, 1987); monocrotophos and endosulfan (three applications of endosulfan starting at flower initiation at 20 days interval) (Samolo and Patnaik, 1986); cypermethrin or dimethoate at flowering or when egg numbers reached two per meter row, and repeated at $10-15$ days interval (Rahman, 1991); cypermethrin, deltamethrin, fenvalerate, and endosulfan (three sprays) (Sontakke and Mishra, 1991); triazophos, endosulfan, and monocrotophos (Sundara Babu and Rajasekaran, 1984); endosulfan + miraculan (a plant growth stimulant), fenvalerate, and monocrotophos (Venkaria and Vyas, 1985); and benomyl+monocrotophos and permethrin (Oladiran, 1990) are also effective against this pest. Some of these insccticides are too expensive for small scale farmers and efforts are needed to avoid application of highly toxic broad spectrum insecticides.

\section{Spray schedules}

Atachi and Sourokou (1989) reported that a sequence of deltamethrin-dimethoate-deltamethrin sprays resulted in the highest grain yield $(1367 \mathrm{~kg} / \mathrm{ha})$. Spray regimes which terminated early offered better protection against the pod borer, but were inadequate for controlling sucking insects (Dina, 1988). Calendar based sprays result in less borer infestation than when sprays are based on economic thresholds (Afun et al., 1991). However, there were no differences in grain yield between the calendar based sprays and those based on economic thresholds. Crop monitoring reduced the number of sprays by half compared to those based on calendar schedules. Four high volume sprays of cypermethrin $0.008 \%$ (1st spray at initiation of flowering, 2nd spray at $50 \%$ flowering, 3rd spray at $100 \%$ flowering, and 4th spray at $100 \%$ pod setting) were effective for protecting the pigeonpea crop against Maruca. This schedule also offered the highest benefit-cost ratio (6.23) (Rahman and Rahman, 1988).

\section{Persistence}

Endosulfan (0.14\%) applied thrice at 20 day intervals resulted in maximum residues $(1.85 \mathrm{ppm})$ (Senapati et al., 1992). Insecticide residues were greater in the husk than the grain. Grain or husk should not be consumed following application of quinalphos or monocrotophos.

\section{Natural pesticides}

Bacillus thuringiensis (Bt) is effective in controlling pod borers (Karel and Schoonhoven, 1986; Otieno and Karikuri, 1991; Supriyatin, 1990). Neem seed powder and neem kernel extract were also effective against legume pod borer (Singh et al, 1985; Hongo and Karel, 1986; Kareem et al., 1989; Tanzubil, 1991; Jackai et al, 1992), but neem seed kernel extract (NSKE) was less effective than fenvalerate and monocrotophos. Defatted neem seed kernel powder applied as a dust to soil around the cowpea plants reduced the pod borer damage and increased the seed yield (Cobbinah and Osei-Owusu, 1988). Ivbijaro and Bolaji (1990) observed that pod borer damage was reduced by four sprays of Azadirachta indica or Piper guineense extracts. Different concentrations of neem oil emulsifiable concentrate (NOEC) $(5,10$, and $20 \%)$ exhibited a high degree of activity against $M$. vitrata (Jackai and Oyediran, 1991). Neem oil slurry emulsifiable concentrate (NOSEC) and 5\% NOEC exhibited similar insecticidal activity, but neem oil and NOEC were superior to NOSEC. Flower infestation was not reduced by 5 and $10 \%$ neem leaf extracts, except in 1994 (Bottenberg and Singh, 1996). Neem leaf extract applied four times on $\mathrm{Cv} 715$ resulted in less pod borer damage than on $\mathrm{CV}$ 941. Neem application reduced pod damage by $12 \%$ in $\mathrm{Cv} 715$, and by $16 \%$ in $\mathrm{Cv} 941$. Neem can be effective in combination with host plant resistance. Isopongaflavone and rotenone are also highly active against the pod borer (Bentley et al., 1987; Lwande et al., 1986), whereas harrisonin and obacunone have antifeedant activity against the larvae (Hassanali et al., 1986).

\section{Conclusions}

Information on the biology of $M$. vitrata has been generated on cowpea, and to a limited extent on pigeonpea. Information on population dynamics (which is essential for developing resistance screening techniques and pest management strategies) and insect density-yield-loss relationships (necessary for estimating economic thresholds, the level of insect infestation needed to screen for host plant resistance, and the desirable levels of resistance needed in the commercial cultivars) still needs to be generated. Screening for resistance has been carried out using natural infestations with multi- and no-choice tests under greenhouse and laboratory conditions. Laboratory/greenhouse tests are useful to confirm the resistance observed under field conditions. Procedures for infestation and evaluation of resistance under field and greenhouse conditions using artificial infestation need to be standardized to breed for plant resistance to this insect. Considerable information has been generated on genotypic resistance/susceptibility to $M$. vitrata in cowpea, while such information on 
pigeonpea and other pulse crops is scanty. Levels of resistance seem to be repeatable across seasons. Several plant characteristics, such as stem and leaf tissue thickness, pod wall thickness, and podding habit (clusters versus spread out pods, pod angle, etc.), have been shown to contribute to less susceptibility to Maruca, and should be integrated with chemical and other control tactics. Some of these characteristics, such as growth habit, pods exposed above the foliage, days to complete flowering, and time required for pod maturity, can be used to select genotypes as possible candidates for resistance to Maruca. The relative contribution of these traits needs to be assessed in a diverse array of genotypes with resistance to Maruca. This will also help to identify lines with different mechanisms of resistance, which can be used in the resistance breeding program to increase the levels and diversify the bases of resistance to $M$. vitrata. Several natural enemies have been reported on $M$. vitrata. Usefulness and effectiveness of Bacillus thuringiensis may be explored for integrated management. Cultural practices, such as intercropping, weeding, time of planting, planting density, and pruning, has been shown to reduce the damage by legume pod borer. However, the results are not consistent over seasons, and locations. Such studies should be repcated involving large plots, and possibly including genotypes that are less susceptible to this insect. Several insecticides have been evaluated for the control of this insect. Future studies should focus on timing of insecticide application based on economic thresholds. Various control options for minimizing the losses due to $M$. vitrata should be tested on farmers ficlds in collaboration with the NARS and other organizations. A network of IARCs working on Maruca may be established to share information for integrated management of $M$. vitrata.

\section{Acknowledgements}

I thank Ms S. Prasanalakshmi with the literature search, and Dr L. Singh for encouragement to undertake this assignment. Approved as JA No 2212 by ICRISAT.

\section{References}

Afun, J. V. K., Jackai, L. E. N. and Hodgson, C. J. (1991) Calendar and monitored insecticide application for the control of cowpea pests. Crop Prot. 10, 363-370

Agyen-Sampong, A. (1978) Pests of cowpea and their control in Ghana. In Pests of Grain Legumes: Ecology and Control, ed. Singh, S. R., van Emden, H. F. and Taylor, J. A. Academic Press, London, pp. 85-92

Ahmed, K., Khalique, F. and Bashir, M. (1987) Insect pests of pulse crops and their control. In Proceedings, Integrated Pest Management, 22 Nov.-3 Dec. 1987, Islamabad, Pakistan, ed. Inayatullah, C. Pakistan Agricultural Research Council, Islamabad, pp. $240-252$

Akhauri, R. K., Sinha, M. M. and Yadav, R. P. (1994) Population build-up and relative abundance of pod borer complex in early pigeonpea, Cajanus cajan (L.) Millsp.. J. Entomol. Res. 18, $121-126$
Akinfenwa, S. (1975) Biological study of Maruca testulalis (Geyer) (Lepidoptera: Pyralidae) in the Zaria area of northern Nigeria. M.Sc. Thesis. Ahmadu Bello University, Nigeria

Akinyemiju, O. A. and Olaifa, J. I. (1987) Influence of weeds and weed control method on insect pests and yields of cowpea (Vigna unguiculata (L.) Walp.). In International Congress of Plant Protection, 5-9 Oct. 1987, Manila, Philippines

Alghali, A. M. (1993) The effects of some agrometereological factors on fluctuation of the legume pod borer, Maruca testulalis Geyer (Lepidoptera: Pyralidae), on two cowpea varieties in Nigeria. Insect Sci. Applic. 14, 55-59

Alghali, A. M. (1993) Intercropping as a component for insect pest management for cowpea Vigna unguiculata Walp. production in Nigeria. Insect Sci. Applic. 14, 49-54

Amatobi, C. J. (1994) Field evaluation of some insecticides for the control of insect pests of cowpea (Vigna unguiculata) in the Sudan savannah of Nigeria. Int. J. Trop. Pest Manage. 40, 13-17

Amatobi, C. J. (1995) Insecticide application for economic production of cowpea grain in the northern Sudan savannah of Nigeria. Int. J. Trop. Pest Management 41, 14-18

Amoako-Atta, B. and Omolo, E. O. (1982) Yield losses caused by the stem-/pod-borer complex within maize-cowpea-sorghum intercropping systems in Kenya. Insect Sci. Applic. 4, 39-46

Amoako-Atta, B., Omolo, E. O. and Kidega, E. K. (1983) Influence of maize, cowpea and sorghum intercropping systems on stem-pod borer infeslations. Insect Sci. Applic. 4, 47-57

Atachi, P. and Ahohuendo, B. C. (1989) Comparison of some parameters characteristic of the population dynamics of Megalurothrips sjostdti (Trybom) and Maruca testulalis (Geyer) on a single plant host (Vigna). Insect Sci. Applic. 10, 187-197

Atachi, P. and Djihou, Z. C. (1994) Record of host plants of Maruca testulalis (Geyer) (Lepidoptera: Pyralidae) in the republic of Benin. Ann. Soc. Ent. Fr. 30, 169-174

Atachi, P. and Sourokou, B. (1989) Use of Decis and Systoate for the control of Maruca testulalis (Geyer) in cowpea. Insect Sci. Applic. 10, 373-381

Barrion, A. T., Bandong, J. P., De la Cruz, C. G., Apostol, R. F. and Litsinger, J. A. (1987) Natural enemies of the bean pod-borer, Marica testulalis in the Philippines. Trop. Gr. Leg. Bull. 34, 21-22

Bentley, M. D., Hassanali, A., Lwande, W., Njoroge, P. E. W., Ole-Sitayo, E. N. and Yatagai, M. (1987) Insect antifeedants from Tephrosia elata Deflers. Insect Sci. Applic. 8, 85-88

Bhalani, P. A. and Prasana, G. J. (1987) Relative toxicity of certain newer insecticides to Maruca testulalis (Geyer) attacking pigeonpea. Pesticides 21, 4 23-25

Booker, R. H. (1965) Pests of cowpea in northern Nigeria. Bull. Ent. Res. 55, 663-672

Bottenberg, H. and Singh, B. B. (1996) Effect of neem leaf extract applied by broom method on cowpea pests and yield. Int. J. Trop. Pest Manage. 42, 207-209

Bruner, S. C. (1931) Informe del Departmento de Entomologia y Fitopatologia, Ejercicio de 1929 a 1930. Experiment Station of Santiago de las Vogas, Cuba

Buranapanichpan, S. and Napompeth, B. (1982) Insect Pests of Pigeonpea in Thailand. Kasetsart University, Bangkok

Cobbinah, J. R. and Osei-Owusu, K. (1988) Effects of neem seed extracts on insect pests of egg plant, okra and cowpea. Insect Sci. Applic. 9, 601-607

Dabrowski, Z. T., Bungu, D. O. M. and Ochieng, R. S. (1983) Studies on the legume pod-borer, Maruca testulalis (Geyer) -3 . Methods used in cowpea screening for resistance. Insect Sci. Applic. 4, 141-145

Das, G. P. and Islam, M. A. (1985) Maruca testulalis (Lepidoptera: Pyralidae): an important pest of country bean in Bangladesh. Bangladesh J. Agric. 10, 57-66

Dharmasena, C. M. D., Subasinghe, S. M. C., Lateef, S. S., Menike, S., Saxena, K. B. and Ariyaratne, H. P. (1992) 
Entomology research. In Pigeonpea Varietal Adaptation and Production Studies in Sri Lanka. Report of Work. Department of Agriculture, Sri Lanka. International Crops Research Institute for the Semi-Arid Tropics (ICRISAT), Patancheru, Andhra Pradesh, pp. 104-108

Dietz, P. A. (1914) Hat katjang-Vlindertje (het vermeende Toa-Toh-Motje). Meded. Deli.Proefatn Medan. 8, 273-278

Dina, S. O. (1988) Timing the application of deltamethrin and cypermethrin for the control of insect pests of cowpea Vigna unguiculata (L.) Walp. Trop. Pest Manage. 34, 65-67

Dina, S. O. and Medaiyedu, J. A. (1976) Field tests with insecticides to control Maruca testulalis and other pod-boring insects of cowpea in southern Nigeria. J. Econ. Entomol. 69, 173-177

Dreyer, H., Baumgartner, J. and Tamo, M. (1994) Seed damaging field pests of cowpea (Vigna unguiculata) (Walp) in Benin: occurrence and pest status. Int. J. Trop. Pest Manage. 40, 252-260

Echendu, T. N. C. and Akingbohungbe, A. E. (1989) The larval populations and plant growth phase for screening cowpea for resistance to Maruca testulalis (Geyer) (Lepidoptera: Pyralidae) in Nigeria based on flowers, pods and yield loss. Trop. Pest Manage. 35, 173-175

Echendu, T. N. C. and Akingbohungbe, A. E. (1990) Intensive free-choice and no-choice cohort tests for evaluating resistance to Maruca testulalis (Lepidoptera: Pyralidae) in cowpea. Bull. Ent. Res. 80, 289-293

Ekesi, S., Dike, M. C. and Ogunlana, M. O. (1996) Relationship between planting dates and damage by the legume pod-borer, Maruca testulalis (Geyer) (Lepidoptera: Pyralidae) on cowpea Vigna unguiculata (L.) Walp in Nigeria. Int. J. Trop. Pest Manage. 42, 315-316

Ezueh. M. I. (1990) Evaluation of the electrodynamic spraying technique for cowpea pest control. Trop. Agric. 67, 77-81

Ezueh, M. I. and Amusan, L. O. (1988) Cowpea insect damage as influenced by the presence of weeds. Agric. Eco. Environ. 21, 255-263

Ezueh, M. I. and Taylor, A. T. (1984) Effects of time of intercropping with maize on cowpea susceptibility to three major pests. Trop. Agric. 61, 82-86

Firempong, S. and Mangalit, H. (1990) Spatial distribution of Maruca testulalis larvae on cowpea, and a sequential sampling plan for estimating larval densities. Insect Sci. Applic. 11, 217-222

Fisher, N. M., Raheja, A. K. and Elemo, K. A. (1987) Insect pest control for cowpea in crop mixtures. Exp. Agric. 23, 9-20

Gethi, M., Omolo, E. O. and Mueke, J. M. (1993) The effect of intercropping on relativc resistance and susceptibility of cowpea cultivars to Maruca testulalis Gever when in mono and when intercropped with maize. Insect Sci. Applic. 14, 305-313

Hassanali, A., Bentley, M. D., Sitayo, E. N. O., Njoroge, P. E. W and Yatagai, M. (1986) Studies on limonoid insect antifeedants Insect Sci. Applic. 7, 495-499

Hongo, H. and Karel, A. K. (1986) Effect of plant extracts on insect pests of common beans. Z. Angew. Entomol. 102, 164-169

Ibrahim, A. G. (1980) Some aspects of the ecology of four insect pests of long beans in Malaysia. In Proceedings, Legumes in the Tropics. Faculty of Agriculture, University Pertanian, Malaysia, pp. $251-257$

ICRISAT (1978) Iulse Entomology (Pigeonpea) Report of Work (June 1977 to May 1978). Progress Report 1. International Crops Research Institute for the Semi-Arid-Tropics, Patancheru, Andhra Pradesh (limited distribution)

ICRISAT (1981) Contribution of Cropping Systems (Entomology) (1974-81). International Crops Research Institute for the Semi Arid-Tropics, Farming Systems Research Program, Patancheru, Andhra Pradesh (limited distribution).

Ivbijaro, M. F. and Bolaji, O. O. (1990) Effects of cypermethrin +dimethoate and extracts of Piper guineense and Azadirachta indica on the pests and yield of cowpea, Vigna unguiculata. $J$. Agric. Sci. 115, 227-231
Iackai, I. E. N. (1981) Relationship between cowpea crop phenology and field infestation by the legume pod-borer, Maruca testulalis. Ann. Entomol. Soc. Am. 74, 402-408

Jackai, L. E. N. (1982) A field screening technique for resistance of cowpea (Vigna unguiculata) to the pod-borer Maruca testulalis (Geyer) (Lepidoptera: Pyralidae). Bull. Ent. Res. 72, 145-156

Jackai, L. E. N. (1983) Efficacy of insecticide applications at different times of day against the legume pod-borer, Maruca tesiulalis (Geyer) (Lepidoptera: Pyralidae), on cowpea in Nigeria. Prot. Ecol. 5, 245-251

Jackai, L. E. N. (1991) Laboratory and screenhouse assays for evaluating cowpea resistance to the legume pod borer. Crop Prot. 10, 48-52

Jackai, L. E. N. and Inang, E. E. (1992) Development profiles of two cowpea pests on resistant and susceptible Vigna genotypes under constant temperatures. J. Appl. Ent. 113, 217-227

Jackai, L. E. N. and Oghiakhe, S. (1989) Pod wall trichomes and resistance of two wild cowpea, Vigna vaxillata, accessions to Maruca testulalis (Geyer) (Lepidoptera: Pyralidae) and Clavigralla tomentosicollis Stal (Hemiptera: Coreidae). Bull. Entomol. Res. 79, 595-605

Jackai, L. E. N. and Oyediran, I. O. (1991) The potential of neem Azadirachta indica A. Juss. for controlling post-flowering pests of cowpea, Vigna unguiculata Walp. l. The pod borer, Maruca testulalis. Insect Sci. Applic. 12, 103-109

Jackai, L. E. N. and Raulston, J. R. (1982) Rearing of the maize stem borers and a legume pod borer on artificial diet. IITA Res. Briefs 3, 1-6

Jackai, L. E. N. and Raulston, J. R. (1988) Rearing of legume pod borer, Maruca testulalis Geyer (Lepidoptera: Pyralidae) on artificial diet. Trop. Pest Manage. 34, 168-172

Jackai, L. E. N. and Singh, S. R. (1983) Suitability of selected leguminous plants for development of Maruca testulalis larvae. Entomol. Exp. Appl. 34, 174-178

Jackai, L. E. N., Franks, P. C. and Alghali, A. M. (1987) Development of an insect pest control strategy for cowpea using the Electrodyn sprayer [Nigeria]. In International Congress of Plant Protection, 5-7 Öct. 1987, Manila, Philippines

Jackai, L. E. N., Inang, E. E. and Nwobi, P. (1992) The potential for controlling post-flowering pests of cowpea, Vigna unguiculata Walp. using neem Azadirachta indica A. Juss.. Trop. Pest Manage. 38, $56-60$

Jackai, L. E. N., Ochieng, R. S. and Raulston, J. R. (1990) Mating and oviposition behavior of the legume pod borer, Maruca testulalis. Entomol. Exp. Appl. 59, 179-186

Kannaiyan, J., Mulila, J. M. and Sithanantham, S. (1987) Bean improvement research in Zambia - progress and prospects. In Troisieme Seminaire Regional sur l'Amelioration du Haricot dans la Region des Grands Lacs, 1987, Kigali, Rwanda, ed. Nyabyenda, P. and Davis, J. Centro International de Agricultura Tropical, Cali, Colombia, and Institut des Sciences Agronomiques du Rwanda, Butare, Rwanda, pp. 63-70

Kareem, A. A., Saxena, R. C. and Palanginan, E. L. (1989) Effect of neem seed bitters (NSB) and neem seed kernel extract (NSKE) on pests of mungbean following rice. Int. Rice Res. Newslett. 13(6), $41-42$

Karel, A. K. (1984) Incidence and control of pod borers on common beans (Phaseolus vulgaris L.). Ann. Rep. Bean Imp. Coop. 27. $189-190$

Karel, A. K. (1985) Yield losses from and control of bean pod borers, Maruca testulalis (Lepidoptera: Pyralidac) and Heliothis armigera (Lepidoptera: Noctuidae). J. Econ. Entomol. 78, $1323-1326$

Karel, A. K. (1993) Effects of intercropping with maize on the incidence and damage caused by pod borers of common beans. Environ. Entomol. 22, 1076-1083

Karel, A. K. and Schoonhoven, A. V. (1986) Use of chemical and microbial insecticides against pests of common beans. J. Econ. Entomol. 79, 1692-1696 
Katayama, J. and Suzuki, I. (1984) Seasonal prevalence of pod borers [Ostrinia scapulalis, Maruca testulalis and Matsumuraeses sp.] in azuki-beans and injury caused by larval infestation. Bull. Kyoto Prefec. Inst. Agric. 12, 27-34

Ke, L. D., Fang, J. L. and Li, Z. T. (1985) Bionomics and control of the legume pod-borer Maruca testulalis Geyer. Acta Entomol. Sin. 28, 51-59

Krishnamurthy, B. (1936) The Avare pod borers. (A new method of control). Mysore Agric. Cal. Yb 25, 29-30

Lamb, K. P. (1978) Pests of winged bean and their control in Papua and New Guinea. In Pests of Grain Legumes: Ecology and Control, ed. Singh, S. R., van Emden, H. F. and Taylor, J. A. Academic Press, London, pp. 53-58

Lateef, S. S. and Reed, W. (1981) Development of methodology for open field screening for insect resistance in pigeonpea. In Proceedings of the International Workshop on Pigeonpea, 15-19 Dec 1980, Vol 2. International Crops Research Institute for the Semi-Arid Tropics, Patancheru, Andhra Pradesh, pp. 315-322

Leonard, M. D. and Mills, A. (1931) A preliminary report on the lima bean pod borer and other legume pod borers in Puerto Rico. J. Econ. Entomol. 24, 466-473

Lwande, W., Bentley, M. D. and Hassanali, A. (1986) The structure of hildecarpin, an insect antifeedant 6a-Hydroxypterocarpan from the roots of Tephrosia hildebrandii Vatke. Insect Sci. Applic. 7, $501-503$

Macfoy, C. A., Dahrowski, Z. T. and Okech, S. (1983) Studies on the legume pod-borer, Maruca testulalis (Geyer) - 4. Cowpea resistance to oviposition and larval feeding. Insect Sci. Applic. 4, $147-152$

Maiga, S. and Issa, H. (1988) Les principaux insectes nuisibles aux cultures pluriales (mil, niebe, sorgho et arachide). In Manuel del'Experimentation en Plein Champ: a l'Usage des Cadres de Development Agricole, ed. Reddy, K. C., Berrada, A. and Bonkarla, A. Institut National de Recherches Agronomiques du Niger, Niamey, pp. 47-72

Marfo, K. O. (1985) Evolving insect pest resistant cowpea varieties in Ghana. Insect Sci. Applic. 6, 385-388

Natarajan, N., Rao, P. V. S. and Gopal, S. (1991) Effect of intercropping of pulscs in cereals on the incidence of major pests. Madras Agric. J. 78, 59-67

Ndoye, M. (1978) Pests of cowpea and their control in Senegal. In Pests of Grain Legumes: Ecology and Control, ed Singh, S. R., van Emden, H. F. and Taylor, J. A. Academic Press, London, pp. $113-116$

Nyiira, Z. M. (1971) The status of insect pests of cowpea (Vigna unguiculata) and their control. PANS 17, 194-197

Ochieng, R. S. and Bungu, M. D. O. (1983) Studies on the legume pod borer, Maruca testulalis (Geyer) - IV. A model for mass rearing. Rearing on artificial diet. Insect Sci. Applic. 4, 83-88

Ochieng, R. S., Okeyo-Owuor, J. B. and Dabrowski, Z. T. (1981) Studies on the legume pod-borer, Maruca testulalis (Geyer) - 2: Mass-rearing on natural food. Insect Sci. Applic. 1, 3 269-272

Odebiyi, J. B. (1981) Studies on the biology of the cowpea pod-borer. Manuca testulalis in Kenya - 1. Determination of the larval instars. Insect Sci. Applic. 1, 339-341

Odindo, M. O. and Jura, W. G. Z. O. (1992) Ultrastructure of Nosema marucae sp.n. (Microspora, Nosematidae), a pathogen of Maruca testulalis (Lepidoptera: Pyralidae). Curr. Microbiol. 25, 339-341

Odulaja, A. and Oghiakhe, S. (1993) A nonlinear model describing yield loss in cowpea (Vigna unguiculata) due to the legume pod borer, Maruca testulalis Geyer (Lepidoptera: Pyralidae). Int. J. Trop. Pest Manage. 39, 61-63

Ofuya, T. I. (1989) Effect of weed removal regimes on postflowering insect damage and grain yield of cowpea, Vigna unguiculata (L.) Walp. in a rain forest area of Nigeria. Trop. Agric. 66, 142-144

Ofuya, T. I. (1991) Observations of insect infestation and damage in cowpea (Vigna unguiculata) intercropped with tomato (Lycoper- sicon esculentum) in a rain forest area of Nigeria. Exp. Agric. 27, $407-412$

Oghiakhe, S. and Odulaja, A. (1993) A multivariate analysis of growth and development parameters of the legume pod-borer, Maruca testulalis on variably resistant cowpea cultivars. Entomol. Exp. Appl. 66, 275-282

Oghiakhe, S. and Odulaja, A. (1993) Classification of cowpea cultivars for field resistance to the legume pod borer, Maruca testulalis in Nigeria using cluster analysis. Ann. Appl. Biol. 122, $69-77$

Oghiakhe, S., Jackai, L. E. N. and Makanjuola, W. A. (1991a) Cowpea plant architecture in relation to infestation and damage by the legume pod-borer, Maruca testulalis (Geyer) (Lepidoptera: Pyralidae) - 1. Effect of canopy structure and pod position. Insect Sci. Applic. 12, 193-199

Oghiakhe, S., Jackai, L. E. N. and Makanjuola, W. A. (1991b) Anatomical parameters of cowpea, Vigna unguiculata (L.) Walp. Stem and pod wall resistance to the legume pod-borer, Maruca testulalis Geyer (Lepidoptera: Pyralidae). Insect Sci. Applic. 12 $171-176$

Oghiakhe, S., Jackai, L. E. N. and Makanjuola, W. A. (1992a) A rapid visual field screening technique for resistance of cowpea (Vigna unguiculata) to the legume pod borer Maruca testulalis (Lepidoptera: Pyralidae). Bull. Entomol. Res. 82, 507-512

Oghiakhe, S., Jackai, L. E. N. and Makanjuola, W. A. (1992b) Cowpea plant architecture in relation to infestation and damage by legume pod-borer, Maruca testulalis (Geyer) (Lepidoptera: Pyralidae) - 2. Effect of pod angle. Insect Sci. Applic. 13, 339-344

Oghiakhe, S., Jackai, L. E. N. and Makanjuola, W. A. (1992c) Pod wall toughness has no effect on cowpea resistance to the legume pod-borer, Maruca testulalis (Geyer) (Lepidoptera: Pyralidae). Insect Sci. Applic. 13, 345-349

Oghiakhe, S., Jackai, L. E. N., Hodgson, C. J. and Ng, O. N (1993a) Anatomical and biochemical parameters of resistance of the wild cowpea, Vigna vexillata Benth. (Au. TVNu 72) to Maruca testulalis Geyer (Lepidoptera: Pyralidae). Insect Sci. Applic. 14, 315-323

Oghiakhe, S., Jackai, L. E. N. and Makanjuola, W. A. (1993b) Cowpea plant architecture in relation to infestation and damage by the legume pod borer, Maruca testulalis Geyer (Lepidoptera: Pyralidae) - 3. Effects of plant growth habit. Insect Sci. Applic. 14, 199-203

Oghiakhe, S., Jackai, L. E. N., Makanjuola, W. A. and Hodgson, C. J. (1992d) Morphology, distribution, and the role of trichomes in cowpea (Vigna unguiculata) resistance to the legume pod borer, Manca testulalis (Lepidoptera: Pyralidae). Bull. Entomol. Res. 82, 499-505

Oghiakhe, S., Makanjuola, W. A. and Jackai, L. E. N. (1993c) Antibiosis mechanism of resistance to the legume pod borer, Maruca testulalis Geyer (Lepidoptera: Pyralidae) in cowpea. Insect Sci. Applic. 14, 403-410

Oghiakhe, S., Makanjuola, W. A. and Jackai, L. E. N. (1993d) The relationship between the concentration of phenol in cowpea and field resistance to the legume pod borer, Maruca testulalis Geyer (Lepidoptera: Pyralidae). Int. J. Trop. Pest Manage. 39, 261-264

Ogunwolu, E. O. (1990) Damage to cowpea by the legume pod borer, Maruca testulalis Geyer, as influenced by infestation density in Nigeria. Trop. Pest Manage. 36, 138-140

Ohno, K. and Alam, M. Z. (1989) Ecological studies on cowpea borers. I. Evaluation of yield loss of cowpea due to the pod borers. In Annual Research Review, 29 Jun 1989. Institute of Postgraduate Studies in Agriculture, Salna, Gazipur, Bangladesh

Okech, S. O. H. and Saxena, K. N. (1990) Responses of Maruca testulalis (Lepidoptera: Pyralidae) larvae to variably resistant cowpea cultivars. Environ. Entomol. 19, 1792-1797

Okeyo-Owuor, J. B. and Ochieng, R. (1981) Studies on the legume pod-borer Maruca testulalis (Geyer) - 1: Iife cycle and behavior. Insect Sci. Applic. 1, 263-268

Okeyo-Owuor, J. B. and Oloo, G. W. (1991) Life tables, key factor analysis and density relations in natural population of the legume 
pod-borer, Maruca testulalis Geyer (Lepidoptera: Pyralidae) in Western Kenya. Insect Sci. Applic. 12, 423-431

Okeyo-Owuor, J. B., Agwaro, P. O. and Simbi, C. O. J. (1983) Studies on the legume pod-borer Maruca testulalis (Geyer) - V. Larval population. Insect Sci. Applic. 4, 75-81

Okeyo-Owuor, J. B., Oloo, G. W. and Agwaro, P. O. (1991) Natural enemies of legume pod-borer, Maruca testulalis (Geyer) (Lepidoptera: Pyralidae) in small farming systems of western Kenya. Insect Sci. Applic. 12, 35-42

Oladiran, A. O. (1990) The effect of fungicides and insecticides singly and in combination on the control of brown blotch, pod borer infestation and yields of Vigna unguiculata (L.) Walp. Trop. Pest Manage. 36, 397-402

Omolo, E. O., Niyambo, S., Simbi, C. O. J. and Ollimo, P. (1993) The role of host plant resistance and intercropping in integrated pest management (IPM) with specific reference to Oyugis project. Int. J. Trop. Pest Manage. 39, 265-272

Onyango, F. O. and Ochieng-Odero, J. P. R. (1993) Laboratory rearing of the legume pod borer, Maruca testulalis Geyer (Lepidoptera: Pyralidae) on a semi-synthetic diet. Insect Sci. Applic. 14, 719-722

Otieno, W. A. (1989) A fungus and a nematode as promising microbial insecticides. In Nineteenth Annual Research Conference of the ICIPE, 7-10 May 1989. International Center for Insect Physiology and Ecology, Nairobi, pp. 10-11

Otieno, W. A. and Karikuri, C. W. (1991) Field efficacy of Bacillus thuringiensis against tropical cereal stem borers, Chilo partellus, Busseola fusca and the legume pod borer, Maruca testulatis in Kenya. In Proceedings, 11th International Congress of Plant Protection, 5-9 Oct. 1987, Manila, Philippines

Otieno, D. A., Hassanali, A. and Nijorogen, P. W. (1985) Chemical basis of TVu 946 stem resistance to Maruca testulalis (Geyer). Insect Sci. Applic, 6, 259-262

Otieno, W. A., Odindo, M. O., Okeyo-Owuor, J. B. and Sabwa, D. M. (1983) Studies on the legume pod-borer, Maruca testulalis Geyer - VII. Field surveys on pathogenic microorganisms. Insect Sci. Applic. 4, 211-215

Patel, R. K. and Singh, D. (1977) Serious incidence of pod-borer Maruca testulalis Gey. on red gram at Varanasi. Sci. Cult. 43(7) 319

Patnaik, N. C., Dash, A. N. and Mishra, B. K. (1989) Effect of intercropping on the incidence of pigeonpea pests in Orissa, India Pigeonpea Newslett. 9, 24-25

Patnaik, H. P., Samolo, A. P. and Samolo, B. N. (1986) Susceptibility of some early varieties of pigeonpea for pod borers under protected conditions. Leg. Res. 9, 7-10

Phelps, R. J. and Oostihuizen, M. J. (1958) Insects injurious to cowpea in Natal region. J. Ent. Soc. Sth. Afr. 21, 286-295

Posada, O. L., Polonia, I. Z. de, Arevalo, I. S. de, Saldarriaga, V., Roa, F. G. and Cardenas, M. R. (1970) Lista de insectos daninos y otras plagas en Colombia. Publ. Miscol. Inst. Colom. Agropec. Vol. 17, $202 \mathrm{pp}$.

Prasad, D., Premchand and Haque, M. F. (1989a) Incidence of pod boring insects in different cultivars of pigeonpea. J. Res., Birsa Agric. Uni. 1, 79-80

Prasad, D., Premchand and Haque, M. F. (1989b) Relative susceptibility of different cultivars of redgram. J. Res., Birsa Agric. Uni. 1 179-181

Raheja, A. I. (1974) Report on the insect pests of grain legumes in northern Nigeria. In Proceedings, 1st IITA Grain Legume Improvement Workshop, 1973. International Institute for Tropical Agriculture, Ibadan, pp. 295-299

Rahman, M. M. (1991) Control measures for important insect pests of major pulses. In Advances in Pulses Research in Bangladesh: Proceedings of the Second National Workshop on Pulses, 6-8 Jun 1989, Joydebpur, Bangladesh. International Crops Research Institute for the Semi-Arid Tropics, Patancheru, Andhra Pradesh, pp. $139-146$
Rahman, M. M. and Rahman, M. S. (1988) Timing and frequency of insecticide application against Maruca testulalis Geyer infesting short-duration pigeonpea in Bangladesh. Leg. Res. 11, 173-179

Ramasubramanian, G. V. and Sundara Babu, P. C. (1988) Effect of host plants on some biological aspects of spotted pod-borer, Maruca testulalis (Lepidoptera: Pyralidae). Indian J. Agric. Sci. 58. 618-620

Ramasubramanian, G. V. and Sundara Babu, P. C. (1989a) Comparative biology of the spotted pod-borer, Manuca testulalis (Geyer) on three host plants. Leg. Res. 12(4), 177-178

Ramasubramanian, G. V. and Sundara Babu, P. C. (1989b) Ovipositional preference of spotted pod-borer, Maruca testulalis (Geyer) (Lepidoptera: Pyralidae). Leg. Res. 12(4), 193-195

Rao, K. T., Rao, N. V. and Reddy, A. S. (1986) Control of pod borers of arhar. Indian Farm. 36(6), 29-35

Rejesus, R. S. (1978) Pests of grain legumes and their control in the Philippines. In Pests of Grain Legumes: Ecology and Control, ed. Singh, S. R., van Emden, H. F. and Taylor, J. A. Academic Press, London, pp. 47-52

Rose, R. I., Chiang, H. S. and Harnoto, I. (1978) Pests of grain legumes and their control in Taiwan. In Pests of Grain Legumes: Ecology and Control, ed. Singh, S. R., van Emden, H. F. and Taylor, J. A. Academic Press, London, pp. 47-52

Ruppel, R. F. and Idrobo, E. (1962) Lista preliminar de insectos y otros animales que danan frijoles en America. Agricultura Trop. 18, $650-678$

Sahoo, B. K. and Patnaik, N. C. (1993) Susceptibility of pigeonpea cultivars to pod borers in Orissa. Int. Pigeonpea Newslett. 18, 31-33

Samolo, A. P. and Patnaik, H. P. (1986) Efficacy of different insecticides and their frequency of application on the pod borers infesting pigeonpea. Madras Agric. J. 73, 352-354

Sarder, M. A. and Kundu, C. D. (1987) A survey of damage estimation of bean pod borer, Maruca testulalis (Geyer) on country beans [of Bangladesh]. In Proceedings of the 12th Annual Bangladesh Science Conference, Section 2. Bangladesh Association for the Advancement of Science, Dhaka, Bangladesh, pp. 18-19

Satsijati, Sunaryono, H. and Darliah (1986) Effect of pruning the tops of some varieties of 'bush-sitao' yardlong bean (Vigna sinensis) on their yield. Bull. Pene. Hort. 14, 85-92

Saxena, H. P. (1978) Pests of grain legumes and their control in India. In Pests of Grain Legumes: Ecology and Control, ed. Singh, S. R., van Emden, H. F. and Taylor, J. A. Academic Press, London, pp. $15-24$

Saxena, K. B., Jayasekera, S. J. B. A. and Ariyaratne, H. P. (1992) Pigeonpea Adoption and Production Studies in Sri Lanka. Department of Agriculture. International Crops Research Institute for the Semi-Arid Tropics, Patancheru, Andhra Pradesh (limited distribution).

Saxena, K. B., Lateef, S. S., Ariyaratne, H. P., Fenseka, H. H. D. and Dharmasena, C. M. D. (1996) Maruca testulalis damage in determinate and indeterminate lines of pigconpea. Int. Pigeonpea Newslett. 3, 91-93

van Schoonhoven, A. (1978) Pests of beans in Latin America and their control. In Pests of Grain Legumes: Ecology and Control, ed Singh, S. R., van Emden, H. F. and Taylor, J. A. Academic Press London, pp. 151-166

Senapati, H. K., Sahoo, B. K., Patnaik, M. R. and Pal, A. K. (1992) Persistence of some common pesticides on pigeonpea in Orissa. J. Agric. Res. 5, 100-103

Sharma, H. C. (1998) Legume pod borer, Maruca vitrata: Insect plant relationships. Insect Sci. Applic. (in press).

Siddig, S. A. (1982) Major pests of faba bean in Sudan. In Proceedings of the Faba Bean Conference, 7-11 March 1981. Cairo Egypt, ed. Hawtin, G. and Web, C. Martinus Nijhoff, Den Haag, pp. $277-273$

Singh, S. R. (1978) Resistance to pests of cowpea in Nigeria. In Pests of Grain Legumes: Ecology and Control, ed. Singh, S. R., van Emden, H. F. and Taylor, T. A. Academic Press, London, pp. $267-279$ 
Singh, S. R. and Allen, D. R. (1980) Pests, diseases, resistance, and protection in cowpea. In Advances in Legume Science, ed. Summerfield, R. J. and Bunting, A. H.). HMSO, London, pp. 419-443

Singh, S. R. and Jackai, L. E. N. (1988) The legume pod-borer, Maruca testulalis (Geyer): past, present and future research. Insect Sci. Applic. 9, 1-5

Singh, R. P., Singh, Y. and Singh, S. P. (1985) Field evaluation of neem (Azadirachta indica A. Juss) seed kernel extracts against the pod borers of pigeonpea, Cajanus cajan (L.) Millsp.. Indian J. Entomol. 47, 111-112

Sontakke, B. K. and Mishra, P. R. (1991) Comparative efficacy and economics of synthetic pyrethroids in the management of pod borer complex of pigeonpea. Indian J. Pl. Prot. 19, 167-170

Srivastava, C. P., Pimbert, M. P. and Jadhav, D. R. (1992) Monitoring of adult population of Maruca testulalis (Geyer) with light traps at Patancheru and Hisar in India. Pigeonpea Newslett. 15, $27-28$

Subasinghe, S. M. C. and Fellows, R. W. (1978) Recent trends in grain legume pest research in Sri Lanka. In Pests of Grain Legumes: Ecology and Control, ed. Singh, S. R., van Emden, H. F. and Taylor, J. A. Academic Press, London, pp. 37-41

Suh, J. B. and Simbi, C. O. (1983) Studies on the legume pod-borer, Maruca testulalis (Geyer) - VIII. Cowpea phenology and yield loss assessment: effect of loss of leaves, shoots, flowers and pods on cowpea yield in western Kenya. Insect Sci. Applic. 4, $89-96$

Sundara Babu, P. C. and Rajasekaran, B. (1984) Studies on the control of pod borers and pod fly on redgram (Cajanus cajan L.). Pesticides 18, 24-26

Supriyatin (1990) Control of mungbean pod borer Maruca testulalis (Lepidoptera: Pyralidae) with chemical and microbial insecticide. In Proceeding of Research Results of Food Crops in Malang Research Institute for Food Crops, 14-15 March 1989, ed. Dahlan, M., Sudaryono, Kasno, A., Suyamto, H., Hartojo, H. K., Saleh, N., Sunardi, and Winarto, A. Malang Research Institute, Indonesia, pp. 50-54

Tanzubil, P. B. (1991) Control of some insect pests of cowpea (Vigna unguiculata) with neem (Azadirachta indica A. Juss.) in northern Ghana. Trop. Pest Manage. 37, 216-217

Taylor, T. A. (1963) The field pests problems in cowpeas in southern Nigeria. In Proceedings, 1st Nigerian Grain Legume Conference. Institute of Agricultural Research, Zaria, Nigeria, pp. $1-8$

Taylor, T. A. (1967) The bionomics of Maruca testulalis Gey. (Lepidoptera: Pyralidae), a major pest of cowpeas in Nigeria. $J$. $W$. Afr. Sci. Ass. 12, 111-129

Taylor, W. E. (1978) Recent trends in grain legume pest research in Sierra Leone. In Pests of Grain Legumes: Ecology and Control, ed. Singh, S. R., van Emden, H. F. and Taylor, J. A. Academic Press, London, pp. 93-98

Tayo, T. O. (1988) Flower and pod development in three cowpea (Vigna unguiculata (L.) Walp.) varieties with varying susceptibility to the pod-borer, Maruca testulalis (Geyer). Insect Sci. Applic. 9, 249-253

Traore, S. (1993) Inventory and distribution of groundnut insect pests in Burkina Faso. In Summary Proceedings of the Third ICRISAT Regional Groundnut Meeting for West Africa, 14-17 Sept. 1992, Ouagadougou, Burkina Faso. International Crops Research Institute for the Semi-Arid Tropics, Patancheru, Andhra Pradesh, pp. 51-52

Turner, J. W. (1978) Pests of grain legumes and their control in Australia. In Pests of Grain Legumes: Ecology and Control, ed. Singh, S. R., van Emden, H. F. and Taylor, J. A. Academic Press, London, pp. 73-81

Usua, E. J. and Singh, S. R. (1977) Parasites and predators of the cowpea pod-borer, Maruca testulalis (Lepidoptera: Pyralidae). Nigerian J. Entomol. 1, 100-102

Usua, E. J. and Singh, S. R. (1979) Behavior of cowpea pod borer, Maruca testulalis Geyer. Nigerian J. Entomol. 3, 231-239

Valdez, P. C. (1989) Host plant resistance in cowpea, Vigna unguiculata (L.) Walp. var. unguiculata, to the pod borer, Maruca testulalis (Geyer) (Lepidoptera: Pyralidae). Philippines University College, Los Banos, Laguna

Venkaria, M. V. and Vyas, H. N. (1985) Chemical control of pod borer complex in greengram, Vigna radiata L. Wilczek with certain insecticides alone and in combination with Miraculan - a plant growth stimulant. Leg. Res. 8, 111-113

Vishakantaiah, M. and Jagadeesh Babu, C. S. (1980) Bionomics of the tur webworm, Maruca testulalis (Lepidoptera: Pyralidae). Mysore J. Agric. Sci. 14, 529-532

Visvanathan, T., Sasitharan, P. and Kareem, A. A. (1983) Compatibility studies with monocrotophos (corophos) 36 WSC and diammonium phosphate in terms of bioefficacy against pod borers in green gram (Vigna radiata L.). Indian J. Farm Chem. 1 , 8-20

Wolcott, G. N. (1933) The Lima bean pod borer caterpillars of Puerto Rico. J. Dept. Agric. P. Rico. 17, 241-255

Wooley, J. N. and Evans, A. M. (1979) Screening for resistance to Maruca testulalis (Geyer) in cowpea (Vigna unguiculata (L.) Walp.). J. Agric. Sci. 92, 417-425

Wooley, J. N. and Evans, A. M. (1984) The use of two mating systems in breeding for resistance to Maruca testulalis Gey. in cowpea Vigna unguiculata (L.) Walp. J. Agric. Sci. 102, 323-331

Received 9 September 1997

Revised 3 March 1998

Accepted 12 May 1998 